\title{
Factors Associated with Burnout Syndrome in Multiprofessional Residents
}

\section{Fatores Associados à Ocorrência da Síndrome de Burnout entre Estudantes de Residências Multiprofissionais}

\author{
Rosângela Fernandes de Oliveira ${ }^{I}$ (iD \\ Maria Amélia Dias Pereira ${ }^{I}$ (iD \\ Matheus Lopes da Silva ${ }^{I} \mathbb{D}$ \\ Matheus Leão Tavares Costa ${ }^{I}$ (iD \\ Érika Carvalho Quirino ${ }^{I}(\mathbb{D}$ \\ Alessandra Vitorino Naghettini ${ }^{I}$ iD
}

\section{KEYWORDS}

- Residence.

- Burnout.

- Teaching.

\section{ABSTRACT}

Introduction: Multiprofessional health residents deal with high stress daily, harming patient care, which can cause emotional and interpersonal reactions that contribute to the development of Burnout Syndrome, thus disclosing the importance of identifying the at-risk conditions for the syndrome and possible protection. The objectives of this study were to describe the occurrence of burnout, its impairment dimensions and the association with sociodemographic characteristics in multiprofessional residency professionals. Method: This is a descriptive research with a quantitative approach, conducted with multiprofessional health residents from public hospitals located in a capital of the Midwest region of Brazil. The ISB - Burnout Syndrome Inventory - was employed, using six indices (Positive Organizational Conditions, Negative Organizational Conditions, Emotional Exhaustion, Emotional Distancing, Dehumanization and Professional Achievement), associated with the assessment of sociodemographic characteristics such as gender, marital status, profession, previous work, change of city, living alone, having children, getting another degree, enjoying what you do in your free time, practicing physical activity, having a religion, undergoing a therapeutic process. The logistic regression method was used to verify the association between these characteristics and the diagnosis of burnout syndrome. A total of 134 residents participated in the survey. Results: The results showed that Emotional Exhaustion is present in 91\% of participants; Emotional Distance in 89.6\%; Dehumanization, in 61.9\%; Professional Achievement in 11.2\%; Positive Organizational Conditions, in 85.1\%; and Negative Organizational Conditions, $n$ 82.1\%. A positive association was observed between taking simultaneous courses, male gender and living alone. Conclusion: It is observed that the practice of therapy can reduce the chance of developing the syndrome and it is concluded that there is a high prevalence of burnout syndrome in the assessed group, with it being a response to stress defined by the presence of exhaustion, distancing and dehumanization. Despite these results, the perception of professional achievement remains independent of stress. 


\section{PALAVRAS-CHAVE}

- Residência.

- Burnout.

- Ensino.

\section{RESUMO}

Introdução: Os residentes multiprofissionais da saúde lidam diariamente com alto nível de estresse, favorecendo o prejuízo ao atendimento do paciente, o que pode causar reações emocionais e interpessoais que contribuem para o desenvolvimento da síndrome de burnout, revelando, assim, a importância de identificar as condições de risco para a síndrome e a possível proteção. O objetivo deste estudo foi descrever a ocorrência de burnout, suas dimensões de comprometimento e a associação com características sociodemográficas entre profissionais da residência multiprofissional. Método: Trata-se de uma pesquisa descritiva, com abordagem quantitativa, realizada com residentes multiprofissionais em saúde de hospitais públicos localizados em uma capital do CentroOeste do Brasil. Adotou-se o Inventário da Síndrome de Burnout (ISB), utilizando-se de seis índices (condições organizacionais positivas, condições organizacionais negativas, exaustão emocional, distanciamento emocional, desumanização e realização profissional), associados à avaliação de características sociodemográficas, como sexo, estado civil, profissão, trabalho anterior, mudança de cidade, morar sozinho, ter filhos, fazer outro curso, gostar do que faz nas horas vagas, praticar atividade física, ter religião, estar em processo terapêutico. O método de regressão logística foi utilizado para verificar a associação entre essas características e o diagnóstico da síndrome de burnout. Participaram da pesquisa 134 residentes. Resultados: Evidenciou-se que a exaustão emocional está presente em 91\% dos participantes; o distanciamento emocional em 89,6\%; a desumanização em 61,9\%; a realização profissional em 11,2\%; as condições organizacionais positivas em 85,1\%; e as condições organizacionais negativas em $82,1 \%$. A associação positiva foi feita entre a realização de cursos simultâneos, a característica sexo masculino e o fato de morar sozinho. Conclusões: Observa-se que a prática de terapia pode reduzir a chance do desenvolvimento da síndrome e conclui-se que há uma alta prevalência da síndrome de burnout no grupo pesquisado, sendo resposta ao estresse definido pela presença de exaustão, distanciamento e desumanização. Apesar desses resultados, a percepção de realização profissional se mantém independente do estresse.

Received on 12/17/19

Accepted on $02 / 19 / 20$

\section{INTRODUCTION}

The multiprofessional residency in health is a lato sensu postgraduate teaching modality for the health professions, considered a specialization course, with the aim of articulating and integrating knowledge into health care. When exercising their daily activities, residents face a demand that is difficult to control, such as severe sequelae, patients with very poor prognosis and death. Feelings of helplessness and guilt are frequent during the work routine, which can have health implications, such as Burnout syndrome ${ }^{1}$.

The professional training processleads students of themultiprofessional residency in health to be present in hospital work environments, facing specific demands from the work environment, compliance with schedules, exposure to risk materials, assuming responsibilities for users, which expose them to a great deal of stress and, consequently, to Burnout, which can lead to great damage to the learning process ${ }^{2}$.
The term Burnout was defined by Maslach and Jackson ${ }^{3}$ as a syndrome of emotional exhaustion, depersonalization and reduced personal achievement, caused by the perpetuation of situations of high emotional demands in the work environment. It is the individual's response to this stress, perceived in the change of posture in relation to professional activities, such as the low performance of functions, distancing and increase in diseases ${ }^{4}$.

In this study we employed the inventory validated by Benevides-Pereira: Inventory of the Burnout Syndrome (ISB, Inventário da Sindrome de Burnout) for the evaluation of the Burnout syndrome. It has three dimensions that represent the syndrome presentation axes: emotional exhaustion, dehumanization and low professional achievement. It evaluates the Positive Operating Conditions (COP, Condições Operacionais Positivas), which promote well-being and quality of life, and Negative Operating Conditions (CON, Condições Operacionais Negativas), which contribute to triggering the syndrome (Table 1).

\begin{tabular}{|c|c|c|c|}
\hline & \multicolumn{3}{|c|}{ Table 1} \\
\hline \multirow{2}{*}{ Indexes } & & isk Classification & \\
\hline & High Risk & Medium Risk & Low Risk \\
\hline Positive Organizational Conditions & Lower than 22 & between 22 and 26 & Greater than 26 \\
\hline Negative Organizational Conditions & Greater than 13 & between 8 and 13 & Lower than 8 \\
\hline Emotional Exhaustion & Greater than 9 & between 4 and 9 & Lower than 4 \\
\hline Emotional Distance & Greater than 6 & between 2 and 6 & Lower than 2 \\
\hline Dehumanization & Greater than 7 & between 4 and 7 & Lower than 4 \\
\hline Professional achievement & Lower than 10 & between 10 and 15 & Greater than 15 \\
\hline
\end{tabular}

Source: Benevides-Pereira ${ }^{5}$

REVISTA BRASILEIRA DE EDUCAÇÃO MÉDICA

2 44 (2) : e060; 2020 
Understanding the teaching-learning scenario and its influence on the well-being of these professionals in the training process is essential, as changes in the work environment provide a correlation with the quality of life and, consequently, with the prevalence of Burnout ${ }^{6}$.

This study aims to identify the occurrence of Burnout Syndrome in residents of the multidisciplinary health residency, assessing the dimensions of commitment and its association with sociodemographic characteristics.

\section{METHOD}

A cross-sectional, descriptive and quantitative study was carried out with residents of the multidisciplinary health residency in Public Hospitals in a capital city in the Midwest region of Brazil. The entire population of 176 residents who were enrolled in the multiprofessional health residency in the municipality from 2016 to 2017 were invited, and 134 accepted the invitation to participate in the study.

The study sample consisted of residents of both genders, with 80 from the first year (R1) and 54 from the second year (R2) from Public Hospitals that offer multiprofessional health residency in the assessed capital, totaling 134 participants.

The exclusion criteria considered residents on vacation or away from academic duties during the data collection period, and these residents were excluded from the research.

Data collection was carried out between the months of August and November 2017, after previous contact with the tutors of each unit, in hospitals where residents carried out their academic and assistance activities.

After explaining the objectives of the study, those who agreed to participate signed the Free and Informed Consent Form (ICF). The assessment instruments were answered individually by the residents, in rooms that guaranteed privacy and secrecy. No instrument was returned incomplete.

For sociodemographic assessment, a questionnaire designed especially for this research was used, which analyzed the following variables: gender, marital status, profession, previous work, change of city, living alone, having children, taking another course simultaneously, enjoying what they do in their spare time, practice physical activity, having a religion and undergoing a therapeutic process.

The instrument used to assess the Burnout syndrome was the Burnout Syndrome Inventory (ISB), developed by Benevides Pereira ${ }^{5}$. This instrument consists of 35 items distributed into two parts (16 and 19 items, respectively). The first part assesses the antecedent or organizational factors indicated by the literature as triggers or modulators of occupational stress processes and, consequently, Burnout, which are divided into Positive Operating Conditions (COP) and Negative Operating Conditions (CON). The second part assesses the syndrome through four dimensions: Emotional Exhaustion (EE); Emotional Distancing (ED); Dehumanization (DH) and Personal Achievement (PA) ${ }^{4}$.

In this assessment instrument, the ED and $\mathrm{DH}$ dimensions are developments of the depersonalization or cynicism described in other tests that assess Burnout. The ISB just adds that division.

The items consist of statements to be answered on a five-point Likert scale, with responses going from " 0 ", as never, to " 4 " as very often in the first part, and in the second part from " 0 " to " 4 ", with 0 being "never" and "4" "every day".

This project was approved by the Ethics and Research Committee, registered under number 70432117.2.0000.5078 and under Opinion n.: $2,209,833$.

Data analysis

To characterize the Burnout Syndrome, six criteria were used (Positive Organizational Conditions, Negative Organizational Conditions, Emotional Exhaustion, Emotional Distancing, Dehumanization and Professional Achievement), of which score determines the risk to which the participant is exposed. It is worth mentioning that Positive Operating Conditions and Professional Achievement correlate with the syndrome in an inverse way when compared to the other variables, with higher numbers representing lower risks.

The individual is characterized as having the syndrome when their score indicates high levels of at least two of the following criteria: Emotional Exhaustion, Emotional Distancing and Dehumanization. These dimensions are considered a key point of the Burnout Syndrome, as they contain interactions between high demands and reduced coping resources, whereas the Professional Achievement dimension does not follow it ${ }^{4}$.

To better detail the distribution of the individuals' scores in relation to each of the indexes, summary measures were used (Median, Mean, Standard Deviation, Minimum and Maximum).

The logistic regression method was used to verify the association between these characteristics and the diagnosis of Burnout Syndrome. A multivariate logistic regression model was also built, where the response variable was adjusted taking into account more than one explanatory variable (covariate). In this model, variables of which p-value was $<0.2$ were included in the bivariate logistic regression analysis.

\section{RESULTS}

Regarding the sociodemographic profile of multiprofessional residents, there was a predominance of women, $89.55 \%$; of single individuals, $81.34 \% ; 68.66 \%$ were from the city where they attend the residency; $75.37 \%$ did not live alone; and $71.64 \%$ did not work before the residency. Only $9.7 \%$ of the participants have children and more than half, $53.73 \%$, do not practice physical activity.

After analyzing the ISB questionnaire, it was observed that, of the 134 interviewed residents, $84.33 \%$ were identified as having Burnout Syndrome.

After analyzing the association between sociodemographic aspects and the presence of Burnout Syndrome, there was a predominance of single residents, $82.3 \%$, those who were taking a concomitant course, $20.4 \%$. The analysis of the association of sociodemographic factors did not identify statistically significant differences between residents who are undergoing a therapeutic process (Table 2).

When evaluating the association by logistic regression, it was observed an increased risk for those who were taking another course at the same time, for males, for those who lived alone and for those who moved to another city, despite not being statistically significant.

The Burnout frequency distribution found among residents according to their respective professions was similar. The lowest frequency of the syndrome was among Psychologists, 75\%, followed by Speech Therapists, $80 \%$. Among social workers, $80 \%$ had the syndrome and, among nurses, $84.62 \%$. Physical therapists, Pharmacists and Nutritionists showed, respectively, $87.5 \%, 87.5 \%$ and $90 \%$ of frequency. Occupational Therapy and Medical Biology showed $100 \%$ of Burnout occurrence, with 4 and 6 assessed residents, respectively.

REVISTA BRASILEIRA DE EDUCAÇ̃̃o MÉDICA

3 44 (2): e060; 2020 


\begin{tabular}{|c|c|c|c|c|c|c|c|c|c|c|c|}
\hline & & \multicolumn{2}{|c|}{$\begin{array}{l}\text { With Burnout } \\
\qquad(n=113)\end{array}$} & \multicolumn{2}{|c|}{$\begin{array}{l}\text { Without Burnout } \\
\qquad(\mathrm{n}=21)\end{array}$} & \multicolumn{2}{|c|}{ Total $(n=134)$} & \multicolumn{4}{|c|}{ Bivariate logistic regression } \\
\hline & & \multirow{2}{*}{$\mathbf{N}$} & \multirow{2}{*}{$\%$} & \multirow{2}{*}{$\mathbf{N}$} & \multirow{2}{*}{$\%$} & \multirow{2}{*}{$\mathbf{N}$} & \multirow{2}{*}{$\%$} & \multirow{2}{*}{ Odds ratio } & \multirow{2}{*}{ P-value ${ }^{*}$} & \multicolumn{2}{|c|}{$95 \% \mathrm{CI}$} \\
\hline & & & & & & & & & & $\mathbf{L L}$ & UL \\
\hline \multirow{2}{*}{ Gender } & Female & 100 & $88.5 \%$ & 20 & $95.2 \%$ & 120 & $89.6 \%$ & - & - & - & - \\
\hline & Male & 13 & $11.5 \%$ & 1 & $4.8 \%$ & 14 & $10.4 \%$ & 2.60 & 0.370 & 0.32 & 21.01 \\
\hline \multirow{2}{*}{ Marital status } & Single or divorced & 93 & $82.3 \%$ & 16 & $76.2 \%$ & 109 & $81.3 \%$ & - & - & - & - \\
\hline & Married & 19 & $16.8 \%$ & 5 & $23.8 \%$ & 24 & $17.9 \%$ & 0.64 & 0.445 & 0.21 & 1.97 \\
\hline \multirow{2}{*}{ Worked before } & No & 84 & $74.3 \%$ & 12 & $57.1 \%$ & 96 & $71.6 \%$ & - & - & - & - \\
\hline & Yes & 29 & $25.7 \%$ & 9 & $42.9 \%$ & 38 & $28.4 \%$ & 0.46 & 0.108 & 0.16 & 1.38 \\
\hline \multirow{2}{*}{ Moved to another city } & No & 76 & $67.3 \%$ & 16 & $76.2 \%$ & 92 & $68.7 \%$ & - & - & - & - \\
\hline & Yes & 37 & $32.7 \%$ & 5 & $23.8 \%$ & 42 & $31.3 \%$ & 1.55 & 0.418 & 0.49 & 5.84 \\
\hline \multirow{2}{*}{ Lives alone } & No & 84 & $74.3 \%$ & 17 & $81.0 \%$ & 101 & $75.4 \%$ & - & - & - & - \\
\hline & Yes & 29 & $25.7 \%$ & 4 & $19.0 \%$ & 33 & $24.6 \%$ & 1.46 & 0.518 & 0.42 & 6.46 \\
\hline \multirow{2}{*}{ Has children } & No & 103 & $91.2 \%$ & 18 & $85.7 \%$ & 121 & $90.3 \%$ & - & - & - & - \\
\hline & Yes & 10 & $8.8 \%$ & 3 & $14.3 \%$ & 13 & $9.7 \%$ & 0.58 & 0.439 & 0.13 & 3.62 \\
\hline \multirow{2}{*}{ Taking another course } & No & 90 & $79.6 \%$ & 20 & $95.2 \%$ & 110 & $82.1 \%$ & - & - & - & - \\
\hline & Yes & 23 & $20.4 \%$ & 1 & $4.8 \%$ & 24 & $17.9 \%$ & 5.11 & 0.080 & 0.73 & 22.88 \\
\hline \multirow{3}{*}{$\begin{array}{l}\text { Like what they do in } \\
\text { their spare time }\end{array}$} & No & 39 & $34.5 \%$ & 4 & $19.0 \%$ & 43 & $32.1 \%$ & - & - & - & - \\
\hline & Sometimes & 20 & $17.7 \%$ & 5 & $23.8 \%$ & 25 & $18.7 \%$ & 0.41 & 0.209 & 0.07 & 2.16 \\
\hline & Yes & 54 & $47.8 \%$ & 12 & $57.1 \%$ & 66 & $49.3 \%$ & 0.46 & 0.200 & 0.10 & 1.68 \\
\hline \multirow{2}{*}{ Physical activity } & No & 60 & $53.1 \%$ & 12 & $57.1 \%$ & 72 & $53.7 \%$ & - & - & - & - \\
\hline & Yes & 53 & $46.9 \%$ & 9 & $42.9 \%$ & 62 & $46.3 \%$ & 1.17 & 0.732 & 0.41 & 3.43 \\
\hline \multirow{2}{*}{ Has a religion } & No & 15 & $13.3 \%$ & 3 & $14.3 \%$ & 18 & $13.4 \%$ & & & & \\
\hline & Yes & 98 & $86.7 \%$ & 18 & $85.7 \%$ & 116 & $86.6 \%$ & 1.08 & 0.900 & 0.18 & 4.44 \\
\hline \multirow{2}{*}{ Therapeutic process } & No & 103 & $91.2 \%$ & 16 & $76.2 \%$ & 119 & $88.8 \%$ & & & & \\
\hline & Yes & 10 & $8.8 \%$ & 5 & $23.8 \%$ & 15 & $11.2 \%$ & 0.31 & 0.040 & 0.08 & 1.32 \\
\hline
\end{tabular}

Note: *table with association of sociodemographic variables with Burnout, according to logistic regression.

In the analysis of the Emotional Exhaustion dimension, the mean score was $15.48 \pm 3.77$, with $91 \%$ of residents belonging to the high-risk category. When evaluating Emotional Distancing, the mean score was $11.57 \pm 4.58$, with $89 \%$ in the high-risk category. In the Dehumanization dimension, the mean score was $8.79 \pm 3.88$, with $61 \%$ of the assessed individuals categorized as high risk.

In the Professional Achievement assessment, the mean score was $13.67 \pm 3.99$, with $57.5 \%$ in a medium risk situation.

When evaluating Positive Operating Conditions, the score was $16.92 \pm$ 4.83 and, in for Negative Operating Conditions, the score was 18.76 5.52, showing a high risk of developing the Burnout Syndrome related to the lack of well-being, quality of life and presence of triggering factors.

\section{DISCUSSION}

In general terms, it was concluded that there was a high frequency of Burnout Syndrome in the assessed group, with high scores for Emotional Exhaustion, Emotional Distancing and Dehumanization.
In the Professional Achievement dimension, the achieved scores demonstrate a lower risk.

The frequency found in the present study of $84.33 \%$ for Burnout Syndrome is higher than that observed by Katsurayama et al. ${ }^{7}$ In an evaluation of 107 medical residents, moderate or high risk was observed in $70 \%$ of the participants as a result of the residence assignments, their focus on patient care in parallel with institutional obligations.

The strenuous work rhythm, perhaps due to the mandatory workload $^{8}$, can be the cause of emotional exhaustion. Sobrinho et al. observed that, of the 291 physicians on duty in an ICU in the city of Salvador, state of Bahia, Brazil, $47.6 \%, 24.7 \%$ and $28.4 \%$ belonged to the high-risk category regarding emotional exhaustion, depersonalization and inefficiency, respectively.

In countries where they invest in Burnout Syndrome prevention through debates and government actions, the prevalence of the syndrome is lower, varying only between 6 and $18 \%^{\mathrm{x}}$. The implementation of professional support programs can be a differential in the training of residents ${ }^{7}$. 
The high risk in the dehumanization dimension can represent a difficulty in interpersonal relationships, with behaviors and attitudes without emotional interest or involvement ${ }^{4}$. Benevides believes that these reported characteristics may also be a form of the individual's defense mechanism.

The dimension of professional achievement was little affected in this study, perhaps because they were professionals at the beginning of their careers, considering that $71.64 \%$ did not work before the residency.

Taking another course simultaneously was an identified risk factor, suggesting that these residents would be exposed to stressors in both training environments, which favor the occurrence of Burnout Syndrome. The maintenance of two simultaneous activities can compromise the health and quality of life of students, due to the strain that these situations cause ${ }^{11}$.

The research indicates that residents who are undergoing a therapeutic process are less likely to develop Burnout, considering it is a moment where they can open up to express themselves. One of the treatments of professional burnout syndrome involves, among other measures, psychotherapy ${ }^{11}$.Despite some limitations observed in this research, such as the difficulty in obtaining a larger number of participants, it is worth emphasizing the need for qualitative research to better define risk factors and protection against Burnout Syndrome. It also highlights the need to promote educational activities and guidance on stress, coping strategies and the dissemination of knowledge about this syndrome to the population. This would allow identifying the stressors and the affected dimensions, in addition to establishing more appropriate strategies to face them, since the prescription of each therapeutic resource depends on the severity and specificity of each case ${ }^{13}$.

\section{FINAL CONSIDERATIONS}

There is a high prevalence of Burnout Syndrome in the different assessed services. The response to stress was mainly defined by the presence of exhaustion, distancing, dehumanization, whereas the professional achievement remains independent of stress. The fact of taking another course simultaneously was considered a risk factor. Those undergoing therapy were less likely to develop the syndrome.

\section{REFERENCES}

1. Guido LA, Silva RM, Goulart CT, Bolzan MEO, Lopes LFD. Síndrome de burnout em residentes multiprofissionais de uma universidade pública. Rev. Esc. Enferm. USP 2012;46 (6):1477-83 [acesso em 15 set 2018]. Disponível em: http://www.scielo.br/pdf/ reeusp/v46n6/27.pdf.

2. Tarnowski M, Carlotto MS. Síndrome de burnout em estudantes de psicologia. Temas psicol. 2007;15(2):173-80 [acesso em 15 set 2018]. Disponível em: http://pepsic.bvsalud.org/pdf/tp/v15n2/04.pdf.

3. Maslach C, Jackson S. Manual MBI, Inventario "Burnout" de Maslach. Madrid: Publicaciones de Psicología Aplicada; 1997.

4. Galdino MJQ, Martins JT, Haddad MCFL, Robazzi MLCC, Birolim MM. Síndrome de burnout entre mestrandos e doutorandos em enfermagem. Acta paul. enferm. 2016;29(1):100-6 [acesso em 15 set 2018]. Disponível em: http://dx.doi.org/10.1590/1982-0194201600014.

5. Benevides Pereira AMT. Elaboração e validação do ISB Inventário para Avaliação da Síndrome de Burnout. Bol. psicol. 2015;LXV(142):59-71 [acesso em 15 set 2018]. Disponível em: http://pepsic.bvsalud.org/pdf/bolpsi/v65n142/v65n142a06.pdf.

6. Mota ID, Farias GO, Silva R, Folle, A. Síndrome de burnout em estudantes universitários: um olhar sobre as investigações. Motrivivência (Florianópolis) 2017;29:243-56 [acesso em 22 set 2018]. Disponível em: https://periodicos.ufsc.br/index.php/motrivivencia/article/view/21758042.2017v29nespp243. doi:10.5007/2175-8042.2017v29nespp243.

7. Katsurayama M, Gomes MN, Becker MAD, Santos MC, Makimoto FH, Santana LLO. Avaliação dos níveis de estresse psicológico em médicos residentes e não residentes de hospitais universitários. Psicol. hosp. 2011;9(1):75-96 [acesso em maio 2018]. Disponível em: http://pepsic.bvsalud.org/pdf/ph/v9n1/v9n1a05.pdf.

8. Brasil. Presidência da República. Casa Civil. Subchefia para Assuntos Jurídicos. Lei no 11.129, de 30 de junho de 2005. Institui a Residência em Área Profissional de Saúde e cria a Comissão Nacional de Residência Multiprofissional em Saúde (CNRMS).

9. Nascimento Sobrinho CL, Barros DS, Tironi MOS, Marques Filho ES. Médicos de UTI: prevalência da síndrome de burnout, características sociodemográficas e condições de trabalho. Rev. bras. educ. med. 2010;34(1):106-15 [acesso em 13 2018]. Disponível em: http://www. scielo.br/pdf/rbem/v34n1/a13v34n1.pdf.

10. Aronsson G, Theorell T, Grape T, Hammarstrõm A, Marteinsdottr I, Skoog I, et al. A systematic review including meta-analysis of work environment and burnout symptoms. BMC public health 2017;17:1-13 [acesso em 13 out 2018]; 17:264. Disponível em: https://bmcpublichealth. biomedcentral.com/track/pdf/10.1186/s12889-017-4153-7.

11. Silva VLS, Chiquinho NC, Andrade RAPO, Brito MFP, Camelo SHH. Fatores de estresse no último ano do curso de graduação em enfermagem: percepção dos estudantes. Rev. enferm. UERJ 2011;19(1):121-6 [acesso em 15 set 2018]. Disponível em: http:// www.facenf.uerj.br/v19n1/v19n1a20.pdf.

12. Silva LC, Salles TLA. O estresse ocupacional e as formas alternativas de tratamento. Recape - Revista de Carreira e Pessoas 2016;6(2):23447 [acesso em 8 set 2018]. Disponível em: http://revistas.pucsp.br/ ReCaPe/article/view/29361/20473.

13. Curiel-García JA, Rodríguez-Morán M, Guerrero-Romero F. Síndrome de agotamiento profesional en personal de atención a la salud. Rev. Méd. Inst. Mex. Seguro Soc. 2006;44(3):221-6 [acesso em 22 set 2018]. Disponível em: https://www.medigraphic.com/pdfs/ imss/im-2006/im063e.pdf.

\section{AUTHORS' CONTRIBUTION}

All authors participated in the study conception, data analysis, literature review and writing of the manuscript.

\section{CONFLICTS OF INTEREST}

The authors declare no conflicts of interest.

\section{ADDRESS FOR CORRESPONDENCE}

Alessandra Vitorino Naghettini

Rua 235 s/n- setor Leste Universitário, Goiânia- Go, 74605-05

Email: alessandra_naghettini@ufg.br 